\title{
Risk Management Process Into Project Lifecycle: A case of Malaysian landscape architecture projects
}

\author{
Adam Aruldewan S.Muthuveeran ${ }^{1}$, Osman Mohd Tahir¹, Roziya Ibrahim¹, \\ Saipol Bari Abd-Karim²
}

${ }^{1}$ Department of Landscape Architecture, Faculty of Design and Architecture, Universiti Putra Malaysia, 43400 Selangor, Malaysia

${ }^{2}$ Center for Building, Construction and Tropical Architecture (BuCTA), Faculty of Built

Environment, University of Malaya, 50603 Kuala Lumpur, Malaysia

aruldewan@yahoo.com; osmanmt@upm.edu.my; roziya@upm.edu.my; saipolbari@um.edu.my

\begin{abstract}
The risk management process is an integral part of all project activities and proportionally customized as one process. This paper prepared to review risk management process integration into the landscape architecture project lifecycle in Malaysia. Data collected from three completed landscape architecture projects studied through structured interviews and project document reviews. The data analyzed using content and thematic analysis. The study found the ineffective risk management process integration into the project lifecycle with the result of the incomplete, unplanned and intended process, and redundant activity ow. Specific integration strategies recommended accommodating landscape architecture project context for practical risk management applications.
\end{abstract}

Keywords: risk management process; project lifecycle; landscape architecture project

eISSN 2398-4295 @2020 The Authors. Published for AMER ABRA cE-Bs by e-International Publishing House, Ltd., UK. This is an open access article under the CC BY-NC-ND license (http://creativecommons.org/licenses/bync-nd/4.0/). Peer-review under responsibility of AMER (Association of Malaysian Environment-Behaviour Researchers), ABRA (Association of Behavioural Researchers on Asians) and CE-Bs (Centre for EnvironmentBehaviour Studies), Faculty of Architecture, Planning \& Surveying, Universiti Teknologi MARA, Malaysia.

DOI: http://dx.doi.org/10.21834/ajbes.v5i18.187 


\subsection{Introduction}

The nature of landscape architecture projects that is dynamic, complex, fast-tracked, and with subjective outcome exposes the projects to a high degree of risk(Capouya et al. 2012; Godi and Sibelius 2012; Meijering et al. 2015; Schatz 2003). This project risk could potentially become a critical issue that hinders the project from achieving its objectives. Malaysia landscape architecture project is part of the construction industry that recognized with a multitude of risks involved. However, risk management in the extension of landscape architecture projects in Malaysia not widely practiced, wherein its risks managed unsystematically (Kurzi and Schroth 2018). Risk management beneficial for construction projects to enhance its performance regularity through precise and systematic risk management during its conception (Keers and van Fenema 2018; Olechowski et al. 2016; Willumsen et al. 2019). It since integrated as part of the project management process (APM 2012; ISO 31000:2018 2018a; PMI 2017).

A risk management system is an established knowledge that vastly practiced worldwide, where most of its standards and guides discuss the principles, process, strategy, and methodology of practice. It is an equally essential management system as environmental management system (Marmaya and Mahbub 2018; Shafie, Omar, and Karuppanan 2018) and health \& safety management system (Ismail et al. 2017; Marhani, Adnan, and Ismail 2018), that commonly applied in Malaysia construction sector. Nevertheless, despite the availability of various risk management standards and guides that landscape architecture project practitioners can refer to and apply, there is a lack of exposure and knowledge in integrating risk management process into the project lifecycle. Most of the standards and guides explain the principles, process, strategy, and methodology of risk management. However, the study found that there are limited reviews on how this integration explained. Only a few authors had attempted to discuss such integration, and even fewer have directly applied it towards construction, particularly on landscape architecture projects.

The project undertaking is significant scope in the landscape architecture industry. The practitioner requires sound knowledge to meet the scope of practice covering all phases of work throughout a project's development (Hasan, Othman, and Ismail 2018). Although a professional landscape architect possesses excellent design and technical knowledge, a management system is needed to systematically warn them of potential risks, quantify the consequences, and determine appropriate actions to control the risks with the best available tools and techniques. Landscape architects face greater risk as liability increases in today's industrial complexity(Meijering et al. 2015). This liability risk is due to several factors; namely, landscape architects are holding more prominent roles in specific projects, increase in the project scope, society being litigious, adoption of new contractual systems, and higher client expectations(Godi and Sibelius 2012; Schatz 2003).A risk management application that involves the process of identifying, analyzing, and responding to the project risk identified as the most appropriate system in delivering successful project outcomes.

The dynamic, complexity and fast-tracked nature common to landscape architecture projects require its risk management application to be integrated holistically into the project management's structure. As explained in the latest ISO 31000:2018 (2018) standard, risk 
management is an integral part of all activities. The risk management process to proportionally customized into the organization's context wherein the combination of these processes would further ease a landscape architect's practice.. In support, Arashpour et al. (2016)posited that this is to counter a fast-tracked and high demanding landscape industry that eradicates the need to focus on the two processes separately. Hence, risk management should integrate into a project's lifecycle as one procedure. Further explained in PMI (2017), such integration needs to be practiced simultaneously and throughout the project's lifecycle to avoid unnecessary redundancy.

Therefore, this paper aims to study the current risk management process application within the project lifecycle. To achieve the aims, following objectives to be accomplished, to analyze landscape architecture project lifecycle, to determine current risk management and its process practice, and to review the effectiveness of risk management process integration into the project lifecycle.

\subsection{Literature Review}

\subsection{Landscape Architecture Project Lifecycle}

The existing knowledge of the project lifecycle from the literature focused on the general construction project activities rather than specially on the landscape architecture profession and scope of practice in the industry(Hanaizal and Mansoor 2019). The study reviewed the project lifecycle from three perspectives, namely project management, construction industry, and landscape management.

A project lifecycle a collection of generally sequential and time-based project phases, whose name and numbers determined by the control needs of the organization involved in the project(APM 2012). The project lifecycle differs across industries and businesses(APM 2012; BS 6079-1:2010 2010). Despite the complex and diverse nature of projects, there is no agreement on the lifecycle phases among industries or even between organizations within the same industry. With a combination of project management, construction industry, and landscape architecture project lifecycle, this study has produceda project lifecycle to suit Malaysia's landscape architecture project scenario that divided into seven phases, as illustrated in Figure 1.

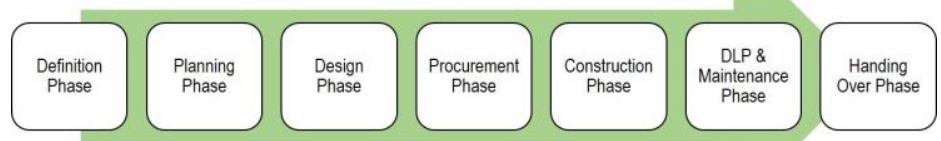

Figure 1: Malaysia's landscape architecture project lifecycle 


\subsection{Risk management process}

The risk management process steps different across various standards and guidelines. It consists of several steps or stages, with the maximum being eight steps. This study concluded there are six necessary steps in the risk management process, namely Communication and Consultation, Establishing the Risk Context, Risk Identification, Risk Analysis, Risk Treatment, and Monitoring and Review. The risk management process steps and stages extracted from eight standards and guidelines illustrated in Figure 2 below. The review of the eight standards and guides indicates that there are various risk management process terminologies and grouping patterns

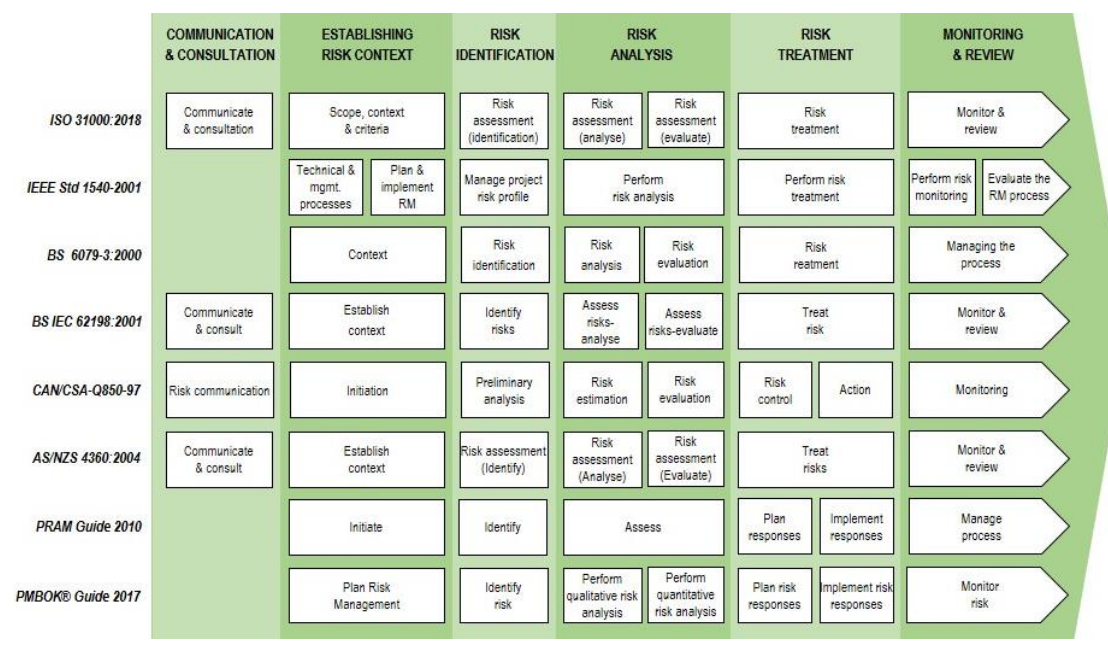

Figure 2: Risk management process extracted from risk management standards and guidelines (Source:APM 2010; AS/NZS 4360:2004 2004; BS 6079-3:2000 2000; BS IEC 62198:2001 2001; CAN/CSA-Q85097 2002; IEEE Std 1540-2001 2001; ISO 31000:2018 2018; PMI 2017)

Discussed in Adnan \& Rosman (2018), Fadzil et al. (2017), Hamzah Abdul-Rahman, Chen Wang (2015), Kang et al. (2015), Mohamed et al. (2014), Omer et al. (2019), and Taofeeq et al. (2020).Malaysia construction industry practiced the risk management process in ill-structured and implemented informally, although a formal risk management process has introduced. Malaysia construction industry adopting simple, quick, reasonable, and inexpensive methods identifying risk instead of managing it in the whole process. Risk not managed comprehensively and not follow the suggested process due to lack of knowledge of risk management implementation and lack of awareness of its benefits.

\subsection{Reviewing Risk management process Application and Integration into Project Lifecycle}


The study reviewed four sources for the risk management process integration into the project lifecycle, which areAPM (2010), Chapman and Ward (2003), ISO 31000:2018 (2018), and PMI (2017). A comparison of these four sources illustrated in Figure 3 below.

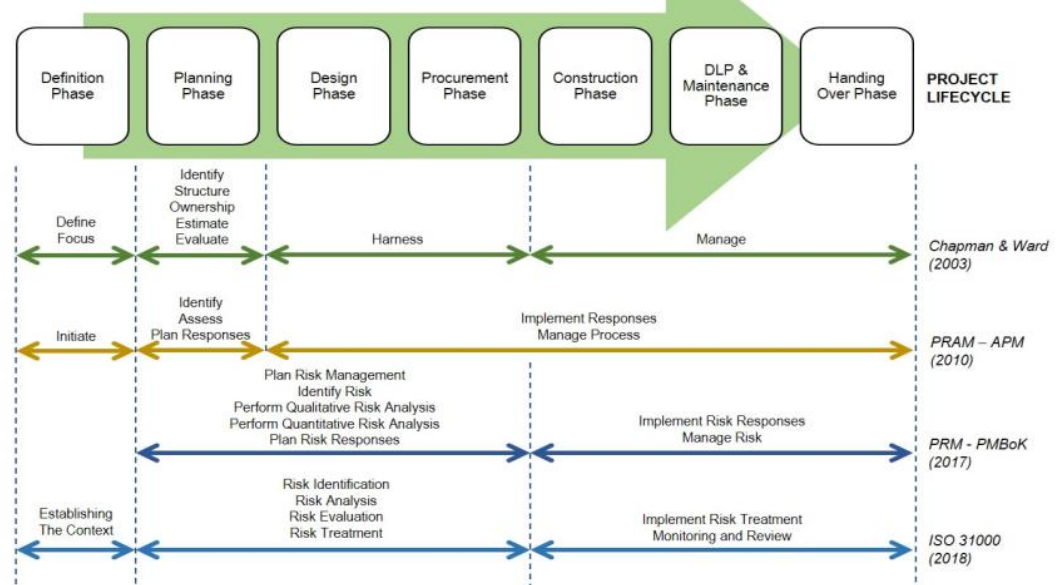

Figure 3: A Comparison of the Risk management process Integration into the Project Lifecycle (Source:APM, 2010; Chapman \& Ward, 2003; ISO 31000:2018, 2018b; PMI, 2017)

Chapman and Ward (2003)suggest in the risk management process to be practice intensely at the earliest phase. The process to complete three iterative cycles that take place towards the end of the planning phase. Adapted and similarly withChapman and Ward (2003), APM (2010)further emphasis completing the risk management process cycle ideally before any significant commitments made possible at the early planning phase. Added, the performing of three cycles known as strategic-level risk management to be completed by the end of the planning phase. The continuum of risk management process performed iteratively and managed concurrently throughout the project lifecycle, known as tactical-level risk management cycles.

Meanwhile, PMI (2017)posited integration indirectly mapped into five project management process groups into nine risk management process steps. Plan risk management, identify risks, perform a qualitative risk analysis, perform a quantitative risk analysis, and plan risk responses practice to be performed under the planning process group, in sequence. Implementation of risk responses is performed during the executing process, while group monitoring of risk performance is performed under the monitoring and controlling process group.ISO 31000:2018 (2018)suggests that the risk management process is theoretically performed in sequence throughout the project lifecycle to three phases: establish the context, assess risks, and then treat the risks. Implementation of risk treatment carried through to the remaining project lifecycle phases. Meanwhile, 
communication and consultation, establishing the context, and monitor and review start earlier and throughout the project lifecycle.

In conclusion, an effective risk management process integration into the project lifecycle should fulfil three aspects, namely process steps' completeness, process activity planning, and process activity ow, as illustrated in Figure 4 below. First, the risk management process should complete all the six-steps, followed in sequential order, and computed in two to three iterative cycles. Second, the risk management process activities are planned and initiated at the earliest phase of the project lifecycle. Finally, in ensuring its success, the risk management process activities should ow as a concurrent process within the project phase and should be continuous throughout the project lifecycle.

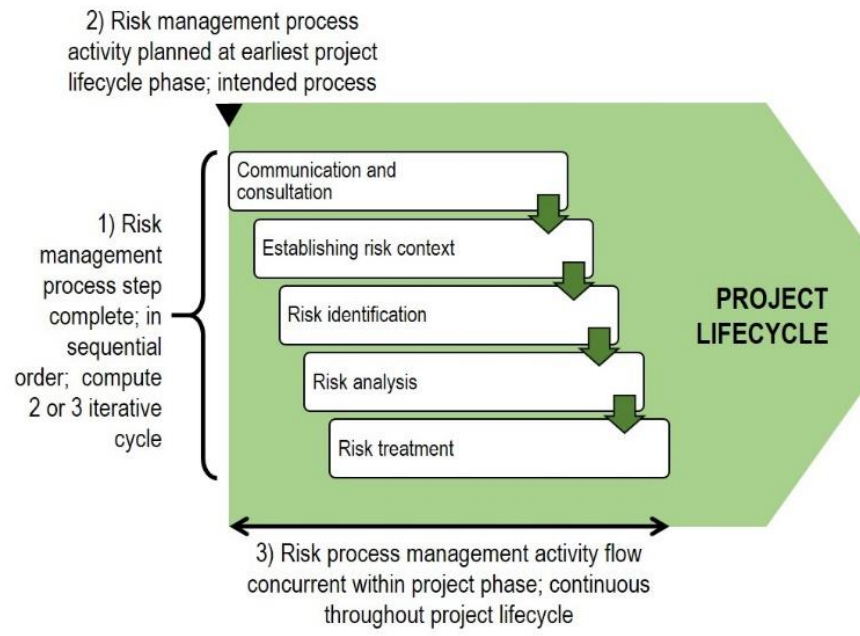

Figure 4:Risk management process integration into the project lifecycle - Extracted aspect for effective intergration

(Source: Author, 2020)

\subsection{Methodology}

This study applied a qualitative case study approach to investigate the effectiveness of risk management process integration into the project lifecycle by way of quantifying the fulfilment of the three aspects discussed above. It engaged an exploratory research purpose that provided flexibility to the researcher to formulate the research development strategy and to develop a systematic process for carrying out the study. The fieldwork data collection gathered through document reviews and structured interviews with project managers from three completed landscape architectural projects. The interviews audio were recorded, transcribed into text, documented, and organized into ATLAS.ti 8 qualitative research software. The data analysis employed a content analysis for describing and interpreting 
deductive codes, categorizing, andfinalizing the themes. Further, a thematic analysis was then employed to synthesize and draw thematic maps between the themes while seeking inductive codes. The analysis includes exploring the relationship between the studied subject categories, seeks patterns, and finally interpreting the results.

Three completed landscape architecture projects were selected based on predetermined sampling criteria. Criteria consisted of; landscape architecture scope of work with traditional procurement route, involved in all project lifecycle phase, completed within the past ten years, and of medium to a largesized project in an urban area within Klang Valley, Malaysia. The projects' information presented in Table 1.

Table 1: Completed landscape architecture project information

\begin{tabular}{|c|c|c|c|}
\hline \multirow{2}{*}{ Detail } & \multicolumn{3}{|c|}{ Landscape Architecture Project } \\
\hline & P1 & P2 & P3 \\
\hline Project Scope & $\begin{array}{c}\text { Soft landscape Works; Hard } \\
\text { Landscape work; } 18 \text { months } \\
\text { Maintenance Works }\end{array}$ & $\begin{array}{l}\text { Planning and Development; } \\
\text { Soft Landscape Works; Hard } \\
\text { landscape work; } 24 \text { months } \\
\text { Maintenance Works }\end{array}$ & $\begin{array}{l}\text { Soft landscape Works; Hard } \\
\text { landscape work; } 24 \text { months } \\
\text { Maintenance Works }\end{array}$ \\
\hline Location & Damansara, Kuala Lumpur & Serdang, Selangor & Shah Alam, Selangor \\
\hline Client & Property Developer & Government & Property Developer \\
\hline Local Authority & $\begin{array}{c}\text { MajisBandaraya } \\
\text { Petaling Jaya }\end{array}$ & $\begin{array}{c}\text { MajlisPerbandaran } \\
\text { Sepang }\end{array}$ & $\begin{array}{c}\text { MajlisBandaraya } \\
\text { Shah Alam }\end{array}$ \\
\hline End user & House owner & Government Institution & House owner \\
\hline Category & Residential & Recreational & Residential \\
\hline Gross Landscape Area & 4 acre & 280 acre & 138 acre \\
\hline $\begin{array}{l}\text { Gross Landscape Work } \\
\text { Cost }\end{array}$ & RM 7 million & RM 29 million & RM 11 million \\
\hline Project Timeline & 33 months & 42 months & 38 months \\
\hline $\begin{array}{l}\text { Construction Tendering } \\
\text { Method }\end{array}$ & Selective & Selective & Selective \\
\hline $\begin{array}{l}\text { Construction Contract } \\
\text { Type }\end{array}$ & Conventional & Conventional Fast Track & Conventional \\
\hline
\end{tabular}

\subsection{Results}

The study investigated a total of twelve project risks identified earlier in the three selected completed projects. Data collected from the structured interviews with the project managers, along with the reviewed project documents, are summarized in Table 2. Then, the effectiveness of the risk management process integration into the project lifecycle reviewed to fulfill three aspects, namely 1) process step completeness, 2) process activity planning, and 3) process activity flow.

Table 2: Project risk

\begin{tabular}{|c|c|c|l|}
\hline Project & $\begin{array}{c}\text { Risk } \\
\text { No. }\end{array}$ & $\begin{array}{c}\text { Risk } \\
\text { Category }\end{array}$ & \multicolumn{1}{|c|}{ Risk Event } \\
\hline P1 & 1.1 & Cost & $\begin{array}{l}\text { Incompetent main contractor management may affect other progress and } \\
\text { delivery. This results in late site hand over, insufficient information feed and poor } \\
\text { site coordination, leading to inaccurate cost estimation and cost overrun }\end{array}$ \\
\hline
\end{tabular}




\begin{tabular}{|c|c|c|c|}
\hline & 1.2 & Technical & $\begin{array}{l}\text { Incompetent contractor to carry out driveway unique structure works. Risk of } \\
\text { structural failure and safety concern }\end{array}$ \\
\hline \multirow[t]{6}{*}{ P2 } & 2.1 & Environment & $\begin{array}{l}\text { Water pollution to project's neighbouring wetland lake due to release of project } \\
\text { residual }\end{array}$ \\
\hline & 2.2 & Planning & $\begin{array}{l}\text { Human traffic and accessibility within project during a major event. Resulted in } \\
\text { event attendees' discomfort and some redundant area not visited due to distance. }\end{array}$ \\
\hline & 2.3 & Organisation & $\begin{array}{l}\text { Change in client's management resulted in delay to the design schedule and not } \\
\text { fully meeting the client's requirement }\end{array}$ \\
\hline & 2.4 & Operation & $\begin{array}{l}\text { Interference on contractor selection based on merit and recommendation by } \\
\text { influential individuals within the client's organisation. This resulted in difficulties } \\
\text { achieving the project deliverables. }\end{array}$ \\
\hline & 2.5 & Operation & $\begin{array}{l}\text { Landscape maintenance and management difficulty due to a large project scope. } \\
\text { Resulted in poor maintenance and constraint in coordination. }\end{array}$ \\
\hline & 2.6 & Schedule & $\begin{array}{l}\text { Delay in planning -design work approval due to internal client's bureaucracy } \\
\text { (change of management; political interference; multiple approval tier). This } \\
\text { resulted in project delay and increased the business operation cost. }\end{array}$ \\
\hline \multirow[t]{4}{*}{ P3 } & 3.1 & Cost & $\begin{array}{l}\text { Additional design work for each house (driveway utilities' slab cover and signage } \\
\text { feature). Scope pushed to the landscape architect from the engineer. Risk to cost } \\
\text { and schedule. }\end{array}$ \\
\hline & 3.2 & Technical & $\begin{array}{l}\text { Technical difficulty on unique water feature - concerns on quality outcome, } \\
\text { buildable practicality and safety }\end{array}$ \\
\hline & 3.3 & Quality & $\begin{array}{l}\text { Underperforming contractor was appointed by the client despite the landscape } \\
\text { consultant's recommendation. Resulted in poor workmanship and defect }\end{array}$ \\
\hline & 3.4 & Schedule & $\begin{array}{l}\text { Delay in design sign-off due to client's slow decision making and multiple tier } \\
\text { approvals. This resulted in delay in construction drawing and tender preparation. }\end{array}$ \\
\hline
\end{tabular}

\subsection{Risk management process step completeness}

The first determinant of effective integration is through the completeness of the six risk management process steps practiced in a project lifecycle. All the projects subjected to such measurements, and it found that the most successful project at integrating all the risk management process steps in the complete order (100\%) is Project P1. Meanwhile, Project P2 practiced 3 out of the $6(50 \%)$ risk management process steps intermittently, and 3 out of $6(50 \%)$ incompletely. Lastly, Project P3 practiced the majority or 3 out of $4(75 \%)$ risk management process steps incompletely. Overall, 6 out of $12(50 \%)$ risks managed incompletely. In summary, it observed that in the studied projects, all the 12 (100\%) common risks in landscape architecture projects identified. However, only $7(58 \%)$ of these risks were analyzed, and $8(67 \%)$ treated. Only $2(17 \%)$ risks communicated, and the risk context established. Meanwhile, a total of $8(67 \%)$ risks monitored. The results tabulated in Table 3.

Table 3: Risk management process step completeness

\begin{tabular}{|c|c|c|c|c|c|c|c|c|c|c|c|c|c|}
\hline \multirow{2}{*}{\multicolumn{2}{|c|}{$\begin{array}{c}\text { Project } \\
\text { Risk No. }\end{array}$}} & \multicolumn{2}{|c|}{ P1 } & \multicolumn{6}{|c|}{ P2 } & \multicolumn{4}{|c|}{ P3 } \\
\hline & & 1.1 & 1.2 & 2.1 & 2.2 & 2.3 & 2.4 & 2.5 & 2.6 & 3.1 & 3.2 & 3.3 & 3.4 \\
\hline \multirow{6}{*}{$\begin{array}{c}\text { Risk } \\
\text { Management } \\
\text { Process } \\
\text { Step }\end{array}$} & Communicate Risk & $\sqrt{ }$ & $\sqrt{ }$ & & & & & & & & & & \\
\hline & Establish Risk Context & $\sqrt{ }$ & $\sqrt{ }$ & & & & & & & & & & \\
\hline & Identify Risk & $\sqrt{ }$ & $\sqrt{ }$ & $\sqrt{ }$ & $\sqrt{ }$ & $\sqrt{ }$ & $\sqrt{ }$ & $\sqrt{ }$ & $\sqrt{ }$ & $\sqrt{ }$ & $\sqrt{ }$ & $\sqrt{ }$ & $\sqrt{ }$ \\
\hline & Analyse Risk & $\sqrt{ }$ & $\sqrt{ }$ & $\sqrt{ }$ & $\sqrt{ }$ & & $\sqrt{ }$ & $\sqrt{ }$ & & $\sqrt{ }$ & $\sqrt{ }$ & & $\sqrt{ }$ \\
\hline & Treat Risk & $\sqrt{ }$ & $\sqrt{ }$ & $\sqrt{ }$ & $\sqrt{ }$ & & & $\sqrt{ }$ & $\sqrt{ }$ & & $\sqrt{ }$ & $\sqrt{ }$ & \\
\hline & Monitor Risk & $\sqrt{ }$ & $\sqrt{ }$ & $\sqrt{ }$ & $\sqrt{ }$ & $\sqrt{ }$ & $\sqrt{ }$ & $\sqrt{ }$ & $\sqrt{ }$ & & & & \\
\hline
\end{tabular}




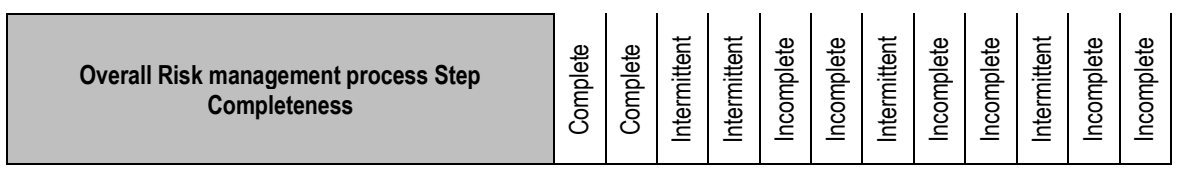

Notes:

Complete : Six (6) risk management process step practiced

Intermittent : Three (3) core risk management process step (Identification-Analysis-Treatment) practiced Incomplete: Three (3) core risk management process step (Identification-Analysis-Treatment) not practiced

\subsection{Risk management process planning and starting point}

In reviewing the effectiveness of the risk management process integration into the project lifecycle, the second factor studied is the risk management process activity planning and starting point. It found that Project P1 recorded a majority or $64 \%$ of the risk activities throughout the project lifecycle encompassing identifying, analyzing, and treating whereby the risk treatment implementation planned concisely and intentionally. Furthermore, other risk activities that are communicating, establishing the context, and monitoring practiced unintentionally. Meanwhile, 59\% of Project P2's risk activities were unplanned and practiced unintentionally. Only two $(7 \%)$ of its risk activities were planned and practiced intentionally. Lastly, similar to Project P2, a majority or 53\% of Project P3's risk activities were unplanned and practiced unintentionally while the risk communicated. The risk management process was often performed in an ad-hoc manner as a reaction towards the risk identification, contributing to only $16 \%$ of planned risk activities with a specific intention to manage it within the project lifecycle, as tabulated in Table 4.

Furthermore, the study reviewed the starting point of the risk activities during the project lifecycle phase. The results showed that 7 out of $12(58 \%)$ risk activities went through the identify-analyze-treat activities at the earliestplanning phase of the project lifecycle. Only 2 out of $12(17 \%)$ identify-analyze-treat risk activities started at the earliest definition phase. The remaining risk activities usually started at the procurement phase. Meanwhile, Project P1 started the communication-establish context-monitor risk activities in the definition phase. In contrast, Projects P2 and P3 ineffectively implemented the communicationestablish context-monitor risk activities at a later phase of their project lifecycle, but mostly no activity was found.

Table 4: Risk management process planning and starting point

\begin{tabular}{|c|c|c|c|c|c|c|c|c|c|c|c|c|c|c|c|c|c|c|c|c|c|c|c|c|c|c|c|c|c|}
\hline \multirow{2}{*}{\multicolumn{2}{|c|}{$\begin{array}{l}\text { Project } \\
\text { Risk No. }\end{array}$}} & \multicolumn{11}{|c|}{ P1 } & \multicolumn{17}{|c|}{$\mathrm{P} 2$} \\
\hline & & & & & 1. & & & & 1.2 & & & & \multicolumn{6}{|c|}{\begin{tabular}{l|l|l} 
& & 2.1 \\
\end{tabular}} & \multicolumn{4}{|c|}{2.2} & \multicolumn{3}{|c|}{2.3} & \multicolumn{4}{|c|}{2.4} \\
\hline \multicolumn{2}{|c|}{$\begin{array}{c}\text { Risk } \\
\text { Management } \\
\text { Process }\end{array}$} & 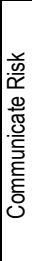 & 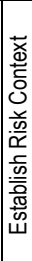 & 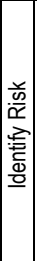 & 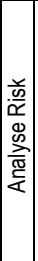 & 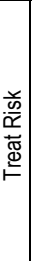 & 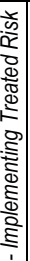 & 总 & 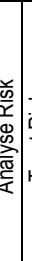 & 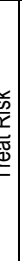 & 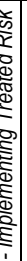 & 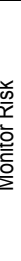 & & 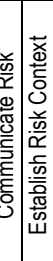 & 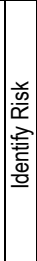 & 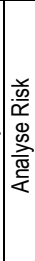 & 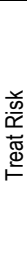 & 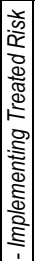 & 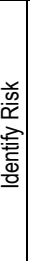 & 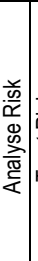 & & 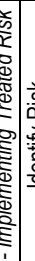 & & & 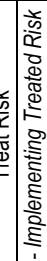 & 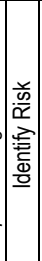 & 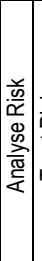 & & 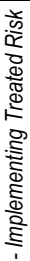 \\
\hline Process & Intended & & & $\sqrt{ }$ & & $\sqrt{ }$ & $\sqrt{ }$ & $\sqrt{ }$ & $\sqrt{ }$ & $\sqrt{ }$ & $\sqrt{ }$ & & & & & & $\sqrt{ }$ & $\sqrt{ }$ & & & & & & & & & & & \\
\hline Activity & Unintended & $\sqrt{ }$ & $\sqrt{ }$ & & $\sqrt{ }$ & & & & & & & $\sqrt{ }$ & $\sqrt{ }$ & $\sqrt{ }$ & $\sqrt{1}$ & $\sqrt{ }$ & & & $\sqrt{ }$ & $\sqrt{ }$ & & 1 & & & & $\sqrt{1}$ & $\sqrt{ }$ & & \\
\hline Planning & \begin{tabular}{|l|} 
Non- \\
\end{tabular} & & & & & & & & & & & & & $\sqrt{1}$ & & & & & & & & $\sqrt{ }$ & & & $\sqrt{ } \mid \sqrt{ }$ & & & & $\sqrt{ }$ \\
\hline
\end{tabular}




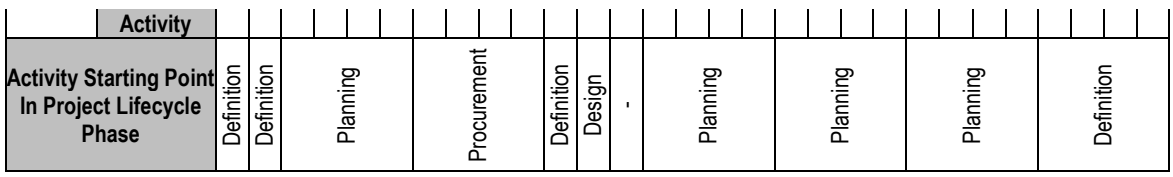

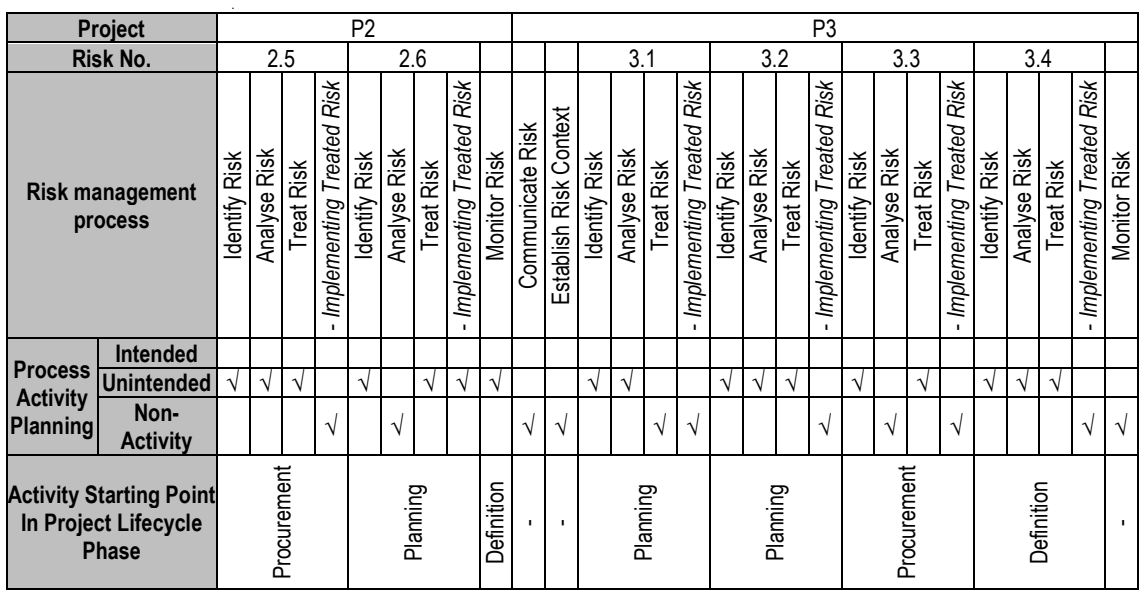

\subsection{Flow of risk management process activities within the project lifecycle}

In reviewing the risk management process integration into the project lifecycle, the third factor studied is the ow of the risk management process steps. Project P1 managed all $(100 \%)$ of the risk management process steps of identify-analyze-treat risks concurrently within its project lifecycle phases. The procedural steps undertaken are common: identify the risk, then the risk would be immediately analyzed and then treated within the same timeframe. In contrast, Project P2 completed the identify-analyze-treat steps in only 3 out of $6(50 \%)$ risks, and the remaining risk management process steps were redundant and incomplete. Besides, 2 out of $6(33 \%)$ risk management process steps were performed consecutively across the different project lifecycle phases. As for P3, the majority or 3 out of $4(75 \%)$ risks had a redundant risk management process activity ow as the steps taken to address risks were incomplete. Overall, 5 out of $12(42 \%)$ of the identify-analyze-treat risk management process steps of Project P3 were redundant as these steps completed in sequence. The ow of the risk management process was usually interrupted and often discontinued afterward. Besides, 4 out of $12(33 \%)$ risk management process steps were performed consecutively across different project lifecycle phases. In practice, risks are usually observed and identifiedduring the definition planning phase of the project. Nonetheless, it would only be critically analyzed and treated later in the procurement phase of the project lifecycle, as tabulated in Table 5.

Table 5: Flow of risk management process activities within the project lifecycle

\begin{tabular}{|c|c|c|c|c|c|c|c|c|c|c|c|c|}
\hline Project & \multicolumn{2}{|c|}{ P1 } & \multicolumn{7}{|c|}{ P2 } & \multicolumn{4}{|c|}{ P3 } \\
\hline Risk No. & 1.1 & 1.2 & 2.1 & 2.2 & 2.3 & 2.4 & 2.5 & 2.6 & 3.1 & 3.2 & 3.3 & 3.4 \\
\hline
\end{tabular}




\begin{tabular}{|c|c|c|c|c|c|c|c|c|c|c|c|c|c|c|c|c|c|c|c|}
\hline \multicolumn{2}{|c|}{$\begin{array}{c}\text { Risk management } \\
\text { process }\end{array}$} & 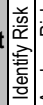 & 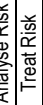 & 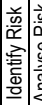 & 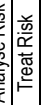 & 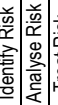 & & & 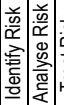 & 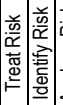 & 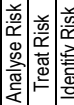 & & 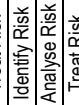 & 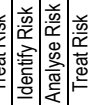 & 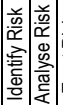 & 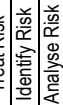 & & & \\
\hline \multirow{6}{*}{ 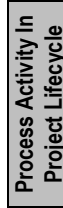 } & Def. & & & & & & & & & $\sqrt{ }$ & & & & & & & & & \\
\hline & Plan. & $\sqrt{1}$ & $\sqrt{ } \sqrt{ }$ & & & 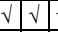 & \begin{tabular}{l|l} 
& $\sqrt{ }$ \\
\end{tabular} & & v & & & & v & $\sqrt{1}$ & \begin{tabular}{|l|l|l|} 
& $v$ \\
\end{tabular} & & & & \\
\hline & Des. & & & & & & & & & & & & & & & & & & \\
\hline & Proc. & & & $\sqrt{ } \mid$ & $\sqrt{ }$ & & & $\begin{array}{llll} & \sqrt{ } \\
\end{array}$ & & & $\mathrm{v}$ & $\mid \sqrt{ }$ & & $\sqrt{ }$ & L & $\sqrt{ }$ & $\sqrt{ }$ & & \\
\hline & Cons. & & & & & & & & & & & & & & d & & & & \\
\hline & $\begin{array}{l}\text { DLP I } \\
\text { Maint. }\end{array}$ & & & & & & & & & & & $\sqrt{ }$ & & & & & & & \\
\hline \multicolumn{2}{|c|}{\begin{tabular}{|c|} 
Overall Risk \\
management \\
process Activity \\
Flow Within \\
Project Lifecycle \\
\end{tabular}} & & D. & c & כ5 & 莺 & & 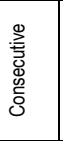 & 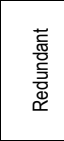 & & 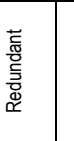 & 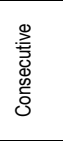 & 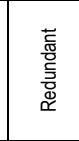 & 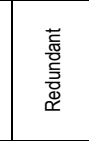 & 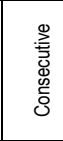 & 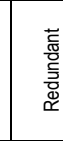 & & 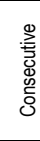 & \\
\hline \multicolumn{2}{|c|}{ Notes: } & & & & & $\begin{array}{l}\text { anage } \\
\text { manag }\end{array}$ & & $\begin{array}{l}t \text { proce } \\
\text { nt proc }\end{array}$ & & $\begin{array}{l}p \text { flow } \\
\text { ep flow } \\
\text { p incom }\end{array}$ & $\begin{array}{l}\text { within so } \\
\text { wacross } \\
\text { mplete }\end{array}$ & $\begin{array}{l}\text { ame pro } \\
\text { differe }\end{array}$ & roject & $\begin{array}{c}\text { cycle } p \\
t \text { lifecy }\end{array}$ & hase & & & & \\
\hline
\end{tabular}

\subsection{Discussion}

The three case studies compared to determine the effectiveness of the risk management process integration into the project lifecycle in terms of risk management process step completeness, risk management process activity planning, and risk management process activity ow. The results summarised in Figure 5. From the illustration, it deduced that Project P1 is moderately effective in integrating the risk management process into its project lifecycle by completing the risk management process steps orderly. Risk activities and intended processes were planned at the earliest outset of the planning phase, while the activity flows concurrently performed within the project phase. In contrast, Project P2 seen as ineffective in integrating the risk management process into its project lifecycle. This evaluation supported evidence that the risk management process practiced during the project lifecycle in an intermittent manner and incomplete sequential steps. The risk management process activities were unplanned and unintended despite the early risk identification at the planning phase. Besides, the complete identify-analyze-treat cycle was performed consecutively across different phases of the project. Besides, some redundant activity flows were also detected. Lastly, Project P3 was the least effective in integrating the risk management process into its project lifecycle, to the extent that the risk management process was mainly practiced in incomplete steps, unplanned, and with a redundant risk management process ow. The findings indicate that based on the six processsteps standard, the risk management process step practiced is incomplete. Most of the projects could identify and treat the project risk but failed to practice the remaining steps. The majority of the risk management processes not well integrated into the project lifecycle. These based on the incomplete steps in the risk management process practice, unplanned risk activities, redundant ow, and incomplete and non-sequential steps. It includes the establishment of the risk context at the earliest instance during the project. Most of the risk 
management process activities happened in an ad-hoc manner as part of the day-to-day project operation and not realized.

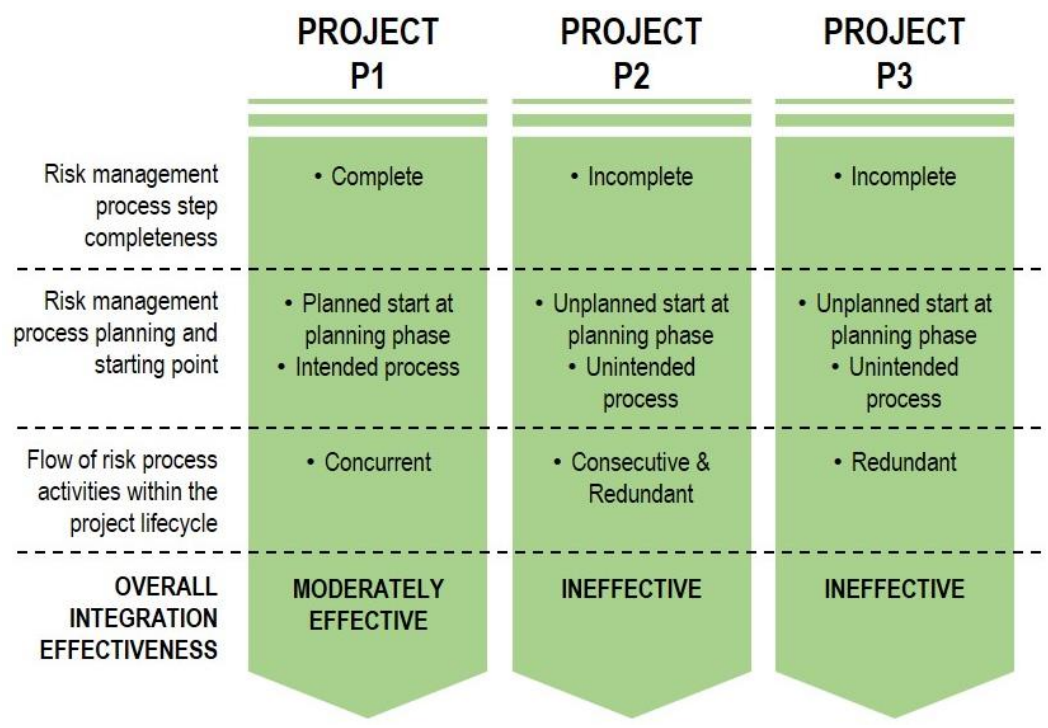

Figure 5: Comparison of the effectiveness of the risk management process integration

In summary, the research estimates that the risk management process integration in Malaysia's landscape architecture project lifecycle is ineffective. This considering factors indicated through incomplete steps in the procedural practices of the risk management process, unplanned risk activity, and redundant ow. This similar practice discussed inAdnan \& Rosman (2018), Fadzil et al. (2017), Hamzah Abdul-Rahman, Chen Wang (2015), Kang et al. (2015), Mohamed et al. (2014), Omer et al. (2019), and Taofeeq et al. (2020). They pointed Malaysian construction risk management process practiced in ill-structured, informal, and not follow suggested steps. The findings demonstrate huge contrast relative to the effective risk management process integration, as suggested byAPM (2010), Chapman \& Ward (2003), ISO 31000:2018 (2018), and PMI (2017),whereby risk management process should practice in a complete and sequential step. It includes the establishment of the risk context at the earliest project phase as well as performing risk communication and monitoring risks continuously throughout the project lifecycle. Additionally, risk management process activity is to be planned at the earliest definition of the project lifecycle phase and performed concurrently within the same timeframe. 


\subsection{Limitation Of Study}

First, the case project focused on preference on urban landscape architecture context, another context not selected. Second, the risk management process integration was only limited within the scope from the initiating phase to handing over the phase, excluding extended project lifecycle that encompasses project benefit realization and management. Third, the risk management process policies, procedures, and practices may be the essential parameter to review the integration effectiveness not explored.

\subsection{Conclusion \& Recommendations}

The study measured three aspects considered in evaluating risk management process integration into the project lifecycle to determine its effectiveness, namely process steps' completeness, process activity planning, and process activity ow. This study concludes the actual landscape architectural practice ineffectively integrates the risk management process into the project lifecycle in contention to suggested risk management literature. This constrained risk management application that further limit the benefits realization. This study may help landscape architecture practitioners to evaluate their current practice and move forward for improvement in regards to risk management. The integration complements risk management application, where project activities could integrate into one inter-related process by which the activities are customizable to the organization's context. This practice will enhance understanding and elevate risk management and its application of landscape architecture projects in Malaysia.

Thus, the further study recommended specific strategies to formulate successful risk management process integration into the project lifecycle. It can complement the context of landscape architecture and supplicates its dynamism through accommodating its complex and fast-tracked nature.

\section{Acknowledgement}

We appreciate the financial support of this study from Geran Putra - Inisiatif Putra Siswazah (GP-IPS), Universiti Putra Malaysia (Project Number: GPIPS/2018/9617500).

\section{References}

Abdul-Rahman, Hamzah, Chen Wang, and Farhanim Sheik Mohamad. 2015. "Implementation of Risk Management in Malaysian Construction Industry: Case Studies." Journal of Construction Engineering 2015(1):7.

Adnan, Hamimah, and Muhammad Redza Rosman. 2018. "Risk Management in Turnkey Projects in Malaysia." WSEAS Transactions on Business and Economics 15:35-43.

APM. 2010. Project Risk Analysis and Management Guide. 2nd ed. edited by APM Risk Management Specific Interest Group. Buckinghamshire: Association for Project Management.

APM. 2012. APM Body of Knowledge. 6th ed. Buckinghamshire: Association for Project Management. 
Arashpour, Mehrdad, Ron Wakefield, E. W. M. Lee, Ricky Chan, and M. Reza Hosseini. 2016. "Analysis of Interacting Uncertainties in On-Site and off-Site Activities: Implications for Hybrid Construction." International Journal of Project Management 34(7):1393-1402.

AS/NZS 4360:2004. 2004. Risk Management Guidelines Companion to AS/NZS 4360:2004. Reissued i. edited by S. A. N. Zealand. Sydney, NSW, Australian/New Zealand: Australian/New Zealand Standard.

BS 6079-1:2010. 2010. Project Management - Part 1: Principles And Guidelines For The Management Of Projects. 3rd ed. London W4 4AL, UK: British Standards Institution (BSI).

BS 6079-3:2000. 2000. Project Management - Part 3: Guide To The Management Of Business Related Project Risk. 1st ed. edited by P. M. Technical Committee MS/2. London W4 4AL, UK: British Standards Institution (BSI).

BS IEC 62198:2001. 2001. Project Risk Management - Application Guidelines. 1st ed. edited by Management Systems Sector Policy and Strategy Committee. London W4 4AL, UK: British Standards Institution (BSI).

CAN/CSA-Q850-97. 2002. Risk Management: Guideline for Decision-Makers. Vol. Raffirmd 2. Ontario, KIP 6N7: The Canadian Standards Association (CSA).

Capouya, Lynn, Karen Compton, Val Dantzler, and Laura Howard. 2012. "Small Firm, Big Risk:Managing Relationships, Resources and Risk in the New Economy." Pp. 1-10 in ASLA 2012 Annual Meeting and EXPO. Arizona: American Society Of Landscape Architects (ASLA).

Chapman, Chris, and Stephen Ward. 2003. Project Risk Management - Processes, Techniques and Insights. 2nd ed. West Sussex P019 8SQ: John Wiley \& Sons Ltd.

Fadzil, Nur Syuhada, Nurazuwa Md Noor, and Ismail Abdul Rahman. 2017. "Need of Risk Management Practice amongst Bumiputera Contractors in Malaysia Construction Industries." P. 7 in IOP Conference Series: Materials Science and Engineering. Vol. 271.

Godi, Donald H., and Troy D. Sibelius. 2012. "Project Risk Management: New Obstacles to Consider." P. 5 in 2012 - ASLA Annual Meeting Presentation, Phoenix Convention Center. Arizona: American Society Of Landscape Architects (ASLA).

Hanaizal, Fatin Ariena Mohd, and Mazlina Mansoor. 2019. "A Review Of Project Development Stages (PLC) In Malaysian Landscape Architecture Industry." Journal of Built Environment, Technology and Engineering 6(May, 2019):42-49.

Hasan, Ramly, Noriah Othman, and Faridah Ismail. 2018. "Choosing Tree for Urban Fabric: Role of Landscape Architect." Pp. 199-207 in 6th AicQoL2018Perhentianlsland, 03-04 March 2018 / E-BPJ, 3(7).

IEEE Std 1540-2001. 2001. IEEE Standard for Software Life Cycle Processes - Risk Management. NY 100165997: The Institute of Electrical and Electronics Engineers, Inc.

Ismail, Faridah, Norizan Ahmad, Nurul Afida Isnaini Janipha, and Razidah Ismail. 2017. "The Behavioural Factors ' Characteristics of Safety Culture." Journal of ASIAN Behavioural Studies (JABs) 2(4):91-98.

ISO 31000:2018. 2018a. ISO 31000:2018 Risk Management - Guidelines. 2nd ed. edited by ISO/TC 262 Risk Management. Geneva 20: International Organization for Standardization (ISO).

ISO 31000:2018. 2018b. Risk Management - Guidelines. 2nd ed. edited by ISO/TC 262 Risk Management. Geneva 20: International Organization for Standardization (ISO).

Kang, Byung Gyoo, Mohamed Ashfaaq Fazlie, Boon Hoe Goh, Myung Kyu Song, and Cheng Zhang. 2015. "Current Practice of Risk Management in the Malaysia Construction Industry - The Process and Tools/Techniques." 
International Journal of Structural and Civil Engineering Research 4(4):371-77.

Keers, Bianca B. M., and Paul C. van Fenema. 2018. "Managing Risks in Public-Private Partnership Formation Projects." International Journal of Project Management 36(6):861-75.

Kurzi, Nurfadilah Saadul, and Olaf Schroth. 2018. "Maintenance and Personal Safety in Neighborhood Parks: A Literature and Case Study of MPSJ." Asian Journal of Quality of Life (AjQoL) 3(13):107-16.

Marhani, Mohd Arif, Hamimah Adnan, and Faridah Ismail. 2018. "OHSAS 18001: Sustainable Construction." Asian Journal of Environment-Behaviour Studies (AjE-Bs) 3(9):95-104.

Marmaya, Ezyana Anyzah, and Rohana Mahbub. 2018. "Evaluation of Environmental Impact and Risk Assessment Methods of Industrial Buildings in Malaysia." Asian Journal of Quality of Life (AjQoL) 3(13):39-47.

Meijering, Jurian Vincent, Hilde Tobi, Adri van den Brink, Fiona Morris, and Diedrich Bruns. 2015. "Exploring Research Priorities in Landscape Architecture: An International Delphi Study." Landscape and Urban Planning 137:85-94.

Mohamed, Othman, Saipol Bari Abd-Karim, Nur Hazwani Roslan, Mohd Suhaimi Mohd Danuri, and Norhanim Zakaria. 2014. "Risk Management: Looming the Modus Operandi among Construction Contractors in Malaysia." International Journal of Construction Management 15(1):82-93.

Olechowski, A., J. Oehmen, W. Seering, and M. Ben-Daya. 2016. "The Professionalization of Risk Management: What Role Can the ISO 31000 Risk Management Principles Play?" International Journal of Project Management 34(8):1568-78.

Omer, Manal Suliman, A. Q. Adeleke, and Kuang Lee Chia. 2019. "Level of Risk Management Practive in Malaysia Construction INdustry From A Knowledge-Based Perspective." Journal of Architecture, Planning and Construction Management 9(1):112-29.

PMI. 2017. A Guide To The Project Management Body Of Knowledge (PMBOK Guide). 6th ed. edited by PMBOK. Pennsylvania 19073-3299 USA: Project Management Institute, Inc.

Schatz, Alex P. 2003. Regulation Of Landscape Architecture And The Protection Of Public Health, Safety, And Welfare. 2003rd ed. Washington, D.C.: The American Society of Landscape Architects.

Shafie, Farah Ayuni, Dasimah Omar, and Subramaniam Karuppanan. 2018. "Environmental Risk Evaluation of a Sanitary Landfill Using Life Cycle Analysis Approach." Asian Journal of Environment-Behaviour Studies (AjE-Bs) 3(8):89-95.

Taofeeq, D. M., A. Q. Adeleke, and Chia Kuang Lee. 2020. "The Synergy between Human Factors and Risk Attitudes of Malaysian Contractors': Moderating Effect of Government Policy." Safety Science 121(September 2019):331-47.

Willumsen, Pelle, Josef Oehmen, Verena Stingl, and Joana Geraldi. 2019. "Value Creation through Project Risk Management." International Journal of Project Management 37(5):731-49. 